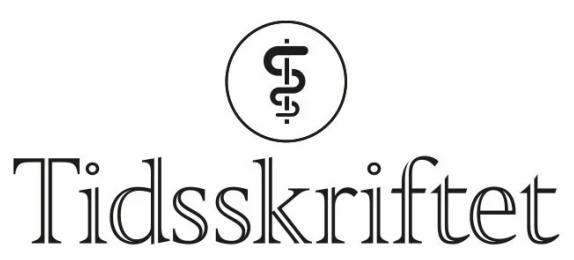

DEN NORSKE LEGEFORENING

\title{
P. Hartvig \& C.F. Haaland svarer:
}

BREV TIL REDAKTØREN

\section{PÅL HARTVIG}

Pål Hartvig (f. 1936) er dr.philos. og spesialist i psykiatri ved Kompetansesenter for sikkerhets-, fengsels- og rettspsykiatri, Oslo universitetssykehus. Ingen oppgitte interessekonflikter. Email: paal.hartvig@gmail.com

\section{CARL FREDRIK HAALAND}

Carl Fredrik Haaland (f. 1962) er spesialist i psykiatri og overlege ved Kompetansesenter for sikkerhets-, fengsels- og rettspsykiatri, Oslo universitetssykehus. Ingen oppgitte interessekonflikter.

Vi takker Tom Gunnar Vik for positiv kommentar til vår kronikk, hvor han også supplerer med sin egen viktige erfaring og kompetanse i dette feltet. Han peker på nødvendigheten av sentrale føringer for å bedre både pasientbehandling og samfunnssikkerhet med gode uteområder. Vi ser også godt at «luftegård» er et ord som i seg selv kan øke opplevelsen av stigmatisering, og således være med på det "gufs» vi antyder i kronikkens tittel. Vi vil gjøre Helsedirektoratet oppmerksom på artikkelen og Viks kommentar, og kanskje kan dette bli starten på sentrale føringer, slik Vik etterlyser, både for navneendring og prioritering av bygningsmessige endringer.

Publisert: 28. oktober 2014. Tidsskr Nor Legeforen. DOI: 10.4045/tidsskr.14.1210

(C) Tidsskrift for Den norske legeforening 2023. Lastet ned fra tidsskriftet.no 26. april 2023. 